\title{
The Emergence Of Entrepreneurial Spirit Through Releasing Mental Block
}

\author{
Larisa Yohanna ${ }^{1}$ and Ridhowati ${ }^{2}$ \\ \{1larisayohanna@gmail.com, ${ }^{2}$ ridhowati.84@gmail.com \\ Universitas Indraprasta PGRI, DKI Jakarta, Indonesia
}

\begin{abstract}
The mental block is a negative belief (harmful thought program) that works at the subconscious level so that unwittingly this program sabotages all the potential on someone. This sabotage mentally/ psychologically works to cover one's mind. It can arise from someone's wrong thoughts about the actual abilities that person has. The entrepreneurial spirit of an entrepreneur or prospective entrepreneur can be dissolved because of a mental block. Therefore, the purpose of these community empowerment activities is as follows: 1) Participants can understand and be able to let go of existing mental blocks/limiting beliefs, and 2) Participants have an entrepreneurial spirit with a mindset that they will become "Success Entrepreneurs." The results of the implementation of community empowerment activities are in line with the expected targets, with the emergence of the enthusiasm of entrepreneurship of the participants. The rise of the spirit of entrepreneurship occurs because of the releasing of mental blocks that have been sabotaging their mindset. It is indicated by the entrepreneurial spirit participants' total score of 311 (78\% of those targeted) and an increase in belief test scores (54\% to $81 \%$ of expectations).
\end{abstract}

Keywords: Mental block, Entrepreneurial spirit, Successful entrepreneurs.

\section{Introduction}

Humans are always faced with a choice in their lives, as an example of choosing to become entrepreneurs or not. In reality, great desires are not always followed by actions of entrepreneurial behaviour from them. Several causes make them want to entrepreneurs but don't dare to start. This cause is also experienced by beginner entrepreneurs, where they finally give up after running their business for one to three years. A person's choice to be an entrepreneur arises from within himself (self-motivation) which is then followed by a sense of enthusiasm and desire to become an entrepreneur. The presence of fear, anxiety and other negative assumptions, make the spirit finally decreased and disappeared in time. For the beginner entrepreneurs, of course, it cannot be separated from all obstacles and risks when at the beginning of starting a business. They just ran a business for a year then gave up, because there was no enthusiasm for entrepreneurship anymore. Although, from the beginning they understood that to be a successful entrepreneur must have a strong mentality, never give up and unafraid of failure. Indeed, the fiery spirit of entrepreneurship fuelled them to continue running the business. Then, with time the spirit faded and could finally disappear. Based on this situation, of course, a solution is needed, so that their entrepreneurial spirit grows and increases. Other fears, anxieties, and mental blocks must be released immediately. If not, 
someone who has the entrepreneurial intention will never start his business, and a novice entrepreneur will not be excited anymore in carrying out the company he has built.

Karang Taruna has a role in building, developing and empowering the potential of the youths of the village to create independence and prosperity[1]. Karang Taruna Mekar Jaya is regularly active with several community empowerment programs, such as batik training, screen printing, handicrafts and more. It is hoped that future young entrepreneurs will be successful with the provision of life skills. In reality, there are only a few young people of Mekar Jaya village who have started a business. They were initially eager to start a business but finally extinguished the spirit. Even though some have already started a business, but they did not focus on running it and eventually did not get excited anymore. Depok Crafter Association (AIKD) is a community name and consists of many members. This community is very active in participating in the bazaar and workshop. The establishment of this community originated from the same interests. Members of the Depok Crafter Association are senior entrepreneurs and beginners. They are often faced that at the beginning of starting, they feel that they are not gifted to be entrepreneurs. As long as the mental block cannot be changed, it is challenging to turn someone from ordinary mentality into an entrepreneurial mindset. The suppression of thoughts can lead to mental blocks [2]. Therefore with the release of mental block/limiting belief is expected to grow and increase the spirit of entrepreneurship for young people and beginner entrepreneurs. The objectives of the community development activities are:

a. Participants know how to let go of the mental block/limiting belief that exists,

b. Participants have an entrepreneurial spirit with a mindset that they are candidates for "Success Entrepreneur."

\section{Methods}

The implementation of community development activity was carried out 1 (one) full day with the following event activities:

Table 1. Event Program

\begin{tabular}{cl}
\hline \multicolumn{1}{c}{ Time } & \multicolumn{1}{c}{ Session } \\
\hline $07.30-08.30$ & $\begin{array}{l}\text { Registration and filling out the questionnaire } \\
\text { Opening and hospitality (while looking at the results } \\
\text { of the initial inquiry) }\end{array}$ \\
$09.30-12.00$ & $\begin{array}{l}\text { Material about Motivation for Entrepreneurship } \\
\text { Break and Lunch }\end{array}$ \\
$12.00-13.15$ & $\begin{array}{l}\text { How to release mental block (Exercise) } \\
15.00-16.00\end{array}$ \\
$16.00-16.30$ & $\begin{array}{l}\text { Questions and Answers } \\
\text { together }\end{array}$ \\
\hline
\end{tabular}

Before the course started, we gave a survey to determine the character of the participants based on the level of adversity quotient [3]: 


\section{a. Quitters}

Characteristics of a Quitter's type person: Opt out, avoid obligations, retreat and stop. He refuses opportunities given by the environment, always feels sad, cynical, and easy to blame others and hate people who are more advanced and developed. Often this person uses selflimiting words like "can't," "don't want," "impossible," "I do not want,".

\section{b. Campers}

Characteristics of a Campers type person: Simply happy with something that has been tried. This kind of person does not want to look for opportunities and feel more satisfied with what has been obtained. He prefers things that are not high risk because they are bored and they avoid trials. This person often releases the opportunity for real progress can still be achieved. He regularly uses of the words "good enough," "we just need .......", "comfort ...".

\section{c. Climbers}

Characteristics of a Climbers type person: He always thinks of "opportunities ... and opportunities", always ready to face challenges with confidence. He understands the purpose of his life. He does not regret failure. He can be relied upon to make a change. He usually uses the words: "there is always a way, "come on ... we do it", and "now is the time to act."

After that, participants were given 30 belief test questions (adapted from Jeffrey Young's 1990 Schema Questionnaire ) to measure participants' beliefs about the essential aspects of life. The lower the score means the higher the level of the mental block [4]. After the team knew the majority of the participants 'character and the mental level of the participants' blocks, the activity was continued by opening their mindset to move forward, have strong beliefs, and dare to take and manage risks to become " Success Entrepreneurs." Then, the team provided a few tips and directed his practice to destroy mental blocks like the feeling "worthless (feeling worthless), hopeless (no expectations) and helpless (powerless)." Below is how to deal with mental blocks [5]:

a. Ask yourself; I am lazy (I am not worthy of success, I am afraid and so on) do not want to do the maximum because ... (you continue the sentence). The sentence after that is the mental block or limiting belief that has hindered participants to be more enthusiastic in entrepreneurship.

b. Creating a positive journal by finding out what the mental block is by writing it in a paper, then replaced by writing the substitute words with affirmative sentences and then adding the phrase "because" then making the reason. After that, visualize until we feel a different sensation as if it happened.

Example: I am not confident when dealing with people who are more powerful than me ( this is a mental block). Replaced with: I am optimistic when dealing with people who are more wide-spread than me because I was also created to be a very successful person. Continue affirmation and visualization. At the end of the activity session, the implementation team provided a questionnaire again to measure the level of entrepreneurial spirit of participants with the following indicators [6]: 


\section{1) They are in-tune with their passion.}

Think of the last thing we have with someone that is deeply passionate about that person. It does not matter if the subject is entirely uninteresting to you, the conviction in their voice and the authentic enthusiasm they have for it is captivating. Passionate people know what it is like to dive deep into a subject and completely understand it. When people are genuinely excited about the problems that your company is trying to solve, they will be energized by any challenge that stands in their way.

\section{2) They are always questioning how it can be done better.}

Mark Twain once said, "Whenever you find yourself on the side of the majority, it is time to pause and reflect." The average person rarely considers how ordinary things can be made better or improved - those with the entrepreneurial spirit cannot help themselves. They are continually questioning why they are not doing so. It was an impressive interview when a candidate had real questions and could be improved.

\section{3) Optimistic about all possibilities}

People with the entrepreneurial spirit do not spend time thinking about what they cannot do, but instead ask themselves, "Why can't I?" When starting up, so you need people are optimistic more than ever. Look for candidates who are excited about the ideas of competitive challenges and big goals - the ones that will push the boundaries of what was once thought impossible.

\section{4) They take calculated risks}

In addition to optimism, entrepreneurs are predisposed to a high tolerance for risk. However, it does not mean they jump blindly into action; it is instead of the opposite. Those with the entrepreneurial spirit make calculated moves while understanding that there are never any guarantees of success. It is also the ability to work autonomously and be decisive. The playbook is not always clear, so it is ideal to be able to say agile and adapt in a high degree of ambiguity.

\section{5) Above all, they execute}

I cannot count the many times I have had aspiring entrepreneurs to come up with advice on their untested ideas. My response is always to go out and act on your ideas first to get real feedback. That is because plans are meaningless until they are worked on. Those with entrepreneurial spirit realize that execution is everything when it comes down to success or failure. They have the drive at all times, no matter what the circumstances.

In this world, success is not a coincidence but is governed by a law whose name is the Law of Cause and Effect. A specific cause will result in the emergence of a particular consequence and in line with that." In other words, a result must have a cause. If "coincidence" is a result, what is the cause that results in "coincidence." Coincidence is the result of the work of our minds. It is just that a belief always limits our minds [7]. The Entrepreneurial spirit is a mindset. It is an attitude and approach to thinking that actively seeks out change, rather than waiting to adapt to change. It is a mindset that embraces critical questioning, innovation, service, and continuous improvement [8]. Belief is a generalization of experience [9]. Whereas mental block is a contrary belief that works at the subconscious level, without knowing this program sabotages all the potential that someone has. The mental block is a mental/psychological obstacle that surrounds a person's mind. It can arise from your 
mistaken thoughts about the real abilities you have [10]. Problems that are related to mental block (limiting belief) and imprint past hold should be released, and it would be a great thing to our vibration. Positive or negative vibration will attract the same (positive and negative) as a result. Have you ever thought of something you do not like? The more you think about it, the worse it might happen. Every day people think 15,000 times and most are negative. So, it is not strange if your bad memories make and creates a limiting belief (mental block) system that affects your life. Therefore, we explained how to release or open the mental block with several techniques introduced by Arif.

At the end of the session, when the participants understood and knew how to release the mental block, the belief test adapted from Jeffrey Young's Schema Questionnaire was given again (in a negative statement). We expected that the mental block decreased with the increasing results on participants' belief test. Also, the emergence of a spirit of entrepreneurship was also highly anticipated (based on entrepreneurial spirit questionnaires).

\section{Result and Discussion}

Participants in community development activities were attended by 10 participants from 30 participants who had been invited, consisting of six men and four women, with $90 \%$ who are not entrepreneurs (whether they had started a business or not).

Table 2. Participants in Community Empowerment Activities

\begin{tabular}{llll}
\hline Name & Gender & Age & Entrepreneur \\
\hline Widya Soleha & P & 19 & No \\
M. Chandra Nugraha & L & 28 & Yes \\
Mega Anjani Putri & P & 19 & No \\
Ahmad Syaban & L & 15 & No \\
M. Ridwan Maulana & L & 16 & No \\
Ramadan fadilah & L & 22 & No \\
Dhea Syafitri & P & 16 & No \\
Ghefira & P & 16 & No \\
Hanifan Ma'ruf & L & 23 & No \\
M. Abdillah & L & 18 & No \\
\hline
\end{tabular}

The measurement of the success of community development activities uses quantitative descriptive in the presentation of the data. At the beginning of the event, the team gave an Adversity Quotient questionnaire to measure their fighting type in achieving a goal. Adversity Quotient is an ability or intelligence of toughness in the form of how well individuals endure trials experienced and how well the individual's strengths can overcome them [11]. 


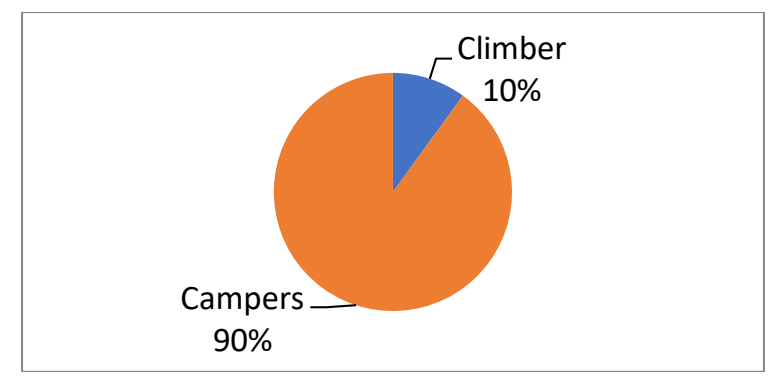

Fig. 1. Adversity Question Type Participant

Based on the picture above $90 \%$ the majority of participants were people who had the motivation and shown an effort and try. However, they were not indeed catch up ambition so that they often chose to stop on some point because they felt tired or bored with challenges faced. It might occur because of negative beliefs (negative thoughts program) which worked on a subconscious level, so unconsciously it sabotages all potential participants' potential. It can arise from the mistakes of the participants' thoughts about the actual abilities of the participants, such as fear, despair, adolescence, and others. It is usually called a mental block. At the beginning of the session, based on a score of pre-test belief of 161, only $54 \%$ of those who were expected to have positive beliefs, with details as follows:

Table 3. Mental Block Participants Before Activities

\begin{tabular}{lll|}
\hline High Mental Block & Score (0-10) & 1 person \\
Medium Mental Block & Score (11-20) & 6 people \\
Low Mental Block & Score (21-30) & 3 people \\
\hline
\end{tabular}

After being given an understanding of the mental block and how to let it go (release), then the decline in participants' mental block, with a total post-test belief of 244 , so that there was an increase to $81 \%$ of the expected. Participants had an increased positive belief in their ability to become "Successful Entrepreneurs." Also, there was a decrease in participants' mental blocks according to table 4 .

Table 4.Mental Block Participants After Activities

\begin{tabular}{lll}
\hline High Mental Block & Score (0-10) & 0 \\
Medium Mental Block & Score (11-20) & 2 people \\
Low Mental Block & Score (21-30) & 8 people \\
\hline
\end{tabular}

Entrepreneurial enthusiasm of participants grew based on the total entrepreneurial spirit score of 311 participants ( $78 \%$ of those targeted). 


\section{Conclussion}

The implementation of community empowerment reached the target as expected with the emergence of an entrepreneurial spirit. The rise of the spirit of entrepreneurship occurred because of the release of mental blocks owned by participants who had been sabotaging their mindset. It was shown by the total entrepreneurial spirit score of 311 participants (78\% of those targeted) and an increase in the test belief score (54\% to $81 \%$ expected). The interest of young people and the general public towards seminars or self-development activities is shallow. It can be seen from 30 invited participants, only 10 participants attended. Although this activity can increase self-awareness, increase self-knowledge, gain new skills, and discover and develop self-potential. Therefore it is necessary to socialize further the management of youth organizations, heads of the village, and a particular community to its members about the importance of self-development in improving the quality of life and contributing to realizing dreams and ideals. Research on the role of letting go mental blocks in increasing entrepreneurial intentions and the spirit of entrepreneurship has never existed. Therefore further research on this matter needs to be done.

\section{Acknowledgements}

The author would like to thanks to the Institute for Research and Service Community of Indraprasta PGRI University who have funded this activity and also to other parties who helped until the event ran smoothly.

\section{References}

[1] Peraturan Menteri Sosial Republik Indonesia Nomor: 77 / HUK / 2010. Pedoman Dasar Karang Taruna, Karang Taruna. https://kemsos.go.id/content/profil-karang-taruna. Accessed 22 January 2018.

[2] Kozak, M., Sternglanz, R.W., Viswanatha. U., and Wegner, D.M. 2008. The Role of Thought Suppression in Building Mental Blocks. Consciousness and Cognition 1. Page 1123-1130.

[3] Yosep, I. and Mardhiyah, A. 2010. Spirit \&amp: Soft Skill of Nursing Entrepreneur. Bandung: PT. Refika Aditama. Page 68

[4] Arif, A. 2012. Menghancurkan Mental Block. Jakarta: Titik Media. Page 154-169.

[5] Arif, A. 2012. Menghancurkan Mental Block. Jakarta: Titik Media. Page 97-115.

[6] Ehrlichman, Matt. 2015. 5 Characteristics of Entrepreneurial Spirit. https://www.inc.com/mattehrlichman/5-characteristics-of-entrepreneurial-spirit.html. Accessed 23 January 2018.

[7] Gunawan, A.W. and Setyono, A. 2008. Becoming A Money Magnet. Jakarta: Gramedia Pustaka Utama. Page 22.

[8] Smith, J. 2013. How To Keep Your Entrepreneurial Spirit Alive As The Company You Work For Grows. $\quad$ https://www.forbes.com/sites/jacquelynsmith/2013/10/22/how-to-keep-yourentrepreneurial-spirit-alive-as-the-company-you-work-for-grows/\#52e2a18cc0d4. Accessed 22 January 2018

[9] Dilts, R. 1990. Beliefs: Pathway to Health and Well-Being. Portland: Metamorphous Press.

[10] Ardi. 2016. Definisi dan Pengertian Mental Blok. http://ardy-web.blogspot.co.id/2016/03/ definisi-dan- pengertian-mental-block.html. Accessed 23 January 2018.

[11] Wangsadinata, W. and Suprayitno, G. 2008. Roosseno: Jembatan dan Menjebatani. Jakarta: Yayasan Obor Indonesia. 